\title{
UNA MOSTRA DEL COL·LAPSE URBÀ A VALENTIA AL S. III D.C.: LES CERÀMIQUES ROMANES DEL CARRER DEL MAR NÚM. 19 (VALÈNCIA, ESPANYA)
}

An Example of the Urban Collapse of Valentia in the $3^{\text {rd }}$ Century A.D.: the Roman Ceramics from Calle del Mar num. 19 (València, Spain)

\section{ESPERANÇA HUGUET ENGUITA}

Investigadora independent. espehuguetenguita@gmail.com

\section{Resum:}

Als anys 80 es practicà una excavació al centre històric de la ciutat de València on aparegué una claveguera totalment cegada per diferents nivells, que contenien abundants materials arqueològics, i el nivell de desguàs d'aquesta. En aquest article s'estudien les ceràmiques que contenia i que han permés datar l'amortització de l'estructura en la segona meitat del s. III d.C.

Paraules clau: Valentia, cloaca, ceràmica romana, colllapse urbà.

\section{Abstract:}

In the 80's, a rescue excavation was practiced in Del Mar street, in the historic centre of Valencia. A sewer, obstructed by different levels with a huge quantity of archaeological remains was identified. Also the associated drainage level was recognized. The study of the ceramic remains allows to date in the second half of the 3rd century A.D. the moment when the structure losed its functionality.

Key words: Valentia, cloaca, Roman pottery, urban collapse. 


\section{INTRODUCCIÓ}

Les constants obres de construcció i rehabilitació realitzades des dels anys 80 en el centre històric de València han permés documentar gran part del subsòl de la ciutat, considerada com a un sol i únic jaciment. Una d'aquestes excavacions es practicà al carrer del Mar núm. 19, sota la direcció de Pepa Pascual, entre febrer i juny de l'any 1985. Aquesta intervenció es situa al sud de la ciutat romana altimperial, molt a prop del recinte emmurallat però fora d'ell a uns 40 m (fig. 1). Tot i que l'excavació estava situada fora del recinte fundacional de la ciutat republicana, s'hi identificaren alguns estrats sense relació amb cap estructura que dataven dels ss. II i I a.C.

Amb el conflicte sertorià la ciutat degué quedar abandonada quasi totalment (Ribera i Jiménez 2012) per a iniciar una represa urbana a mitjan del regnat d'August com demostra la deposició votiva que colmatà el pou republicà de l'Asklepeion de l'Almoina (Albiach et al. 1998; Huguet i Ribera 2015). Les veritables mostres de represa de la vida urbana es donaren a partir de l'època flàvia (Jiménez 2009: 96), quan el recinte de la ciutat s'amplià fins a pràcticament el doble del republicà i es constatà la construcció de diferents edificis de caràcter públic, religiós i comercial. Al carrer del Mar, les primeres estructures daten del final del s. I d.C., una habitació i una cloaca (fig. 2), quan en aquesta àrea es construïren noves edificacions que coincidiren amb l'expansió flàvia de la ciutat (Pascual 1988: 32; Huguet 2016: 178). La construcció de la canalització es pogué datar, com caldria esperar, en aquesta època i el seu final de l'ús a mitjan de s. III. La cloaca estava segellada per un paviment format per còdols de riu entre els quals aparegueren monedes de Gal-liè, Divo Claudio i la Tetrarquia, que permeten datar-lo en la primera meitat del s. IV d.C. Sobre aquesta capa es documentaren construccions i un enterrament dels ss. VI-VII, diversos pous islàmics amb abundant material ceràmic i els fonaments de les construccions dels edificis moderns.

En aquest article tractarem únicament les ceràmiques romanes que han permés datar el final d'ús de la claveguera durant el s. III d.C.

\section{LA CLAVEGUERA}

L'estructura, que presentava una direcció SE, estava composta per dues parets verticals i un terra de morter de calç amb graves i pedres (UE 1053) (fig. 3). Per a la seua construcció es disposaren dues capes superposades: la primera d'elles sobre les sorres de base (UE 1153), amb $15 \mathrm{~cm}$ d'espessor, composta per sorra i pedres; per sobre d'aquesta, la segona era una preparació més gruixuda, d'uns $30 \mathrm{~cm}$, feta amb pedres irregulars (UE 1200). Les seues parets mesuren $1 \mathrm{~m}$ d'altura, $0,50 \mathrm{~m}$ de grossària $\mathrm{i}$ l'espai interior de la claveguera era de $0,85 \mathrm{~m}$. Per sobre

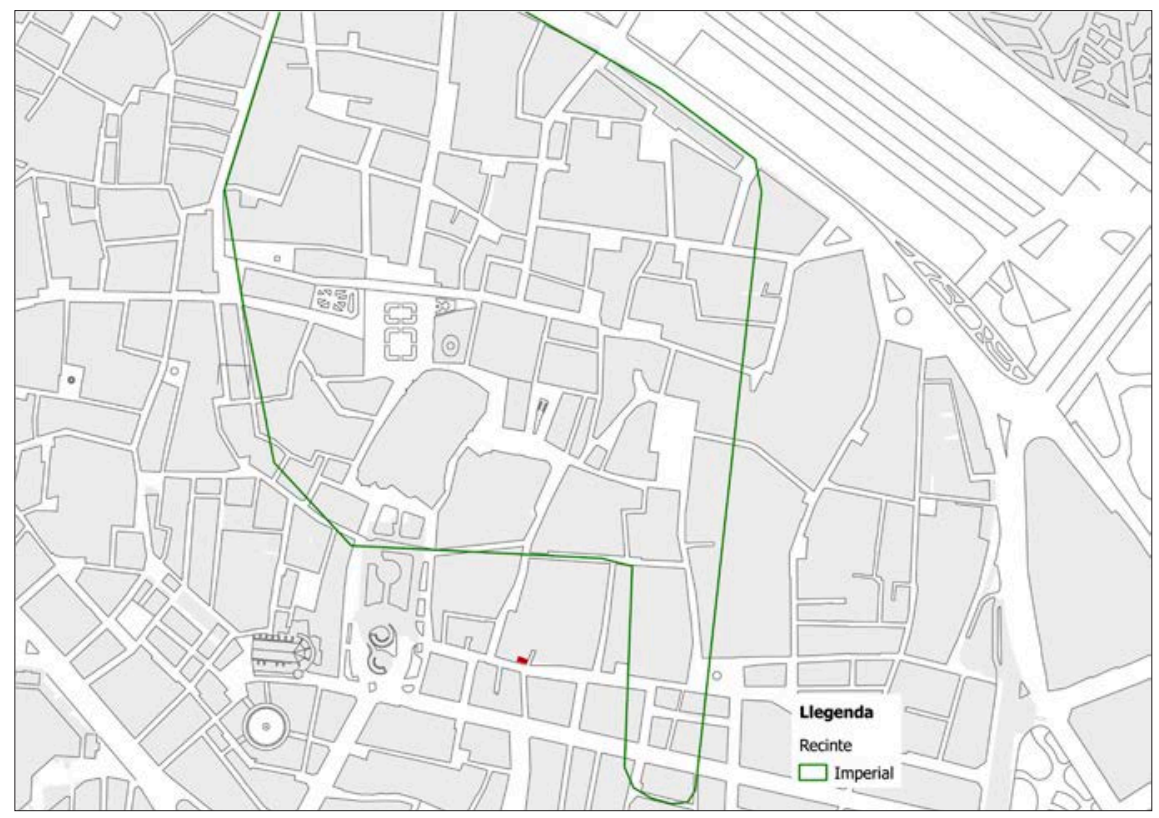

Fig. 1: Plànol de situació de l'excavació i el recinte imperial en l'entramat viari actual. 
Fig. 2: Planta de les estructures trobades a l'excavació del carrer del Mar núm. 19.

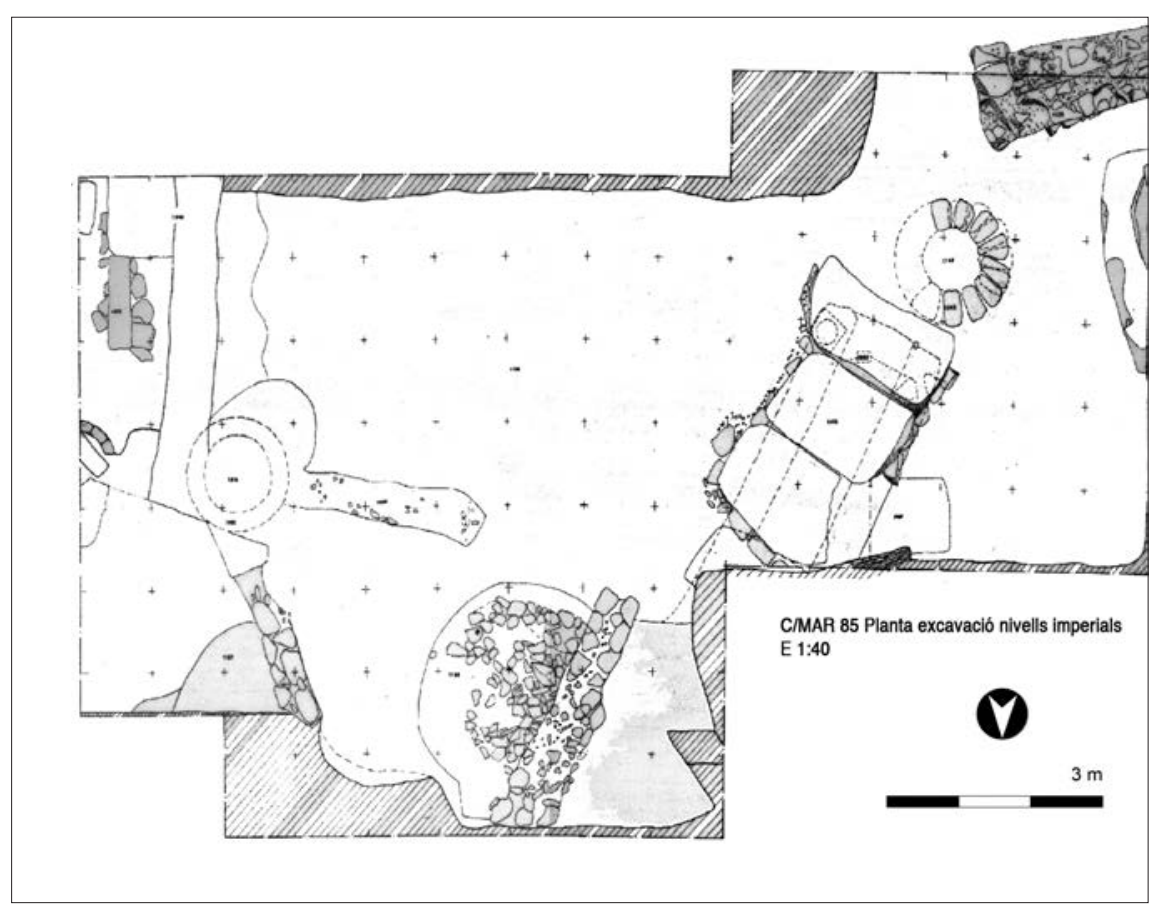

de les parets s'identificà una capa de terra llimosa grisa amb argamassa i pedres mitjanes posades irregularment, junt a una basa de columna (UE 1181). Sobre aquestes s'instal-là la coberta feta per tres grans lloses de forma rectangular (UE 1145), disposades més o menys horitzontalment. Aquesta coberta fou probablement un afegit posterior a la construcció de la claveguera que en principi estaria oberta.

\section{EL REBLIMENT I LA CERÀMICA QUE CONTENIA}

La canalització es trobà completament cegada amb terra i abundantíssim material ceràmic (fig. 4). Es diferenciaren cinc capes successives que presentaven, en la part central, una concavitat probablement degut al pas d'aigua. La successió d'estrats identificats al seu interior té una cronologia uniforme coincident amb la gran acumulació de material identificada en la seua boca. El rebliment de la cloaca degué ser un procés lent però continu produït en la segona meitat del s. III d.C.

El gran conjunt de ceràmiques dels nivells que amortitzaven les estructures de la canalització estava format per un Nombre Mínim d'Individus (NMI) de 288 (figs. 5 i 6), dels quals les àmfores suposaven un 5,2\% del total ceràmic; els percentatges de la vaixella fina es reparteixen

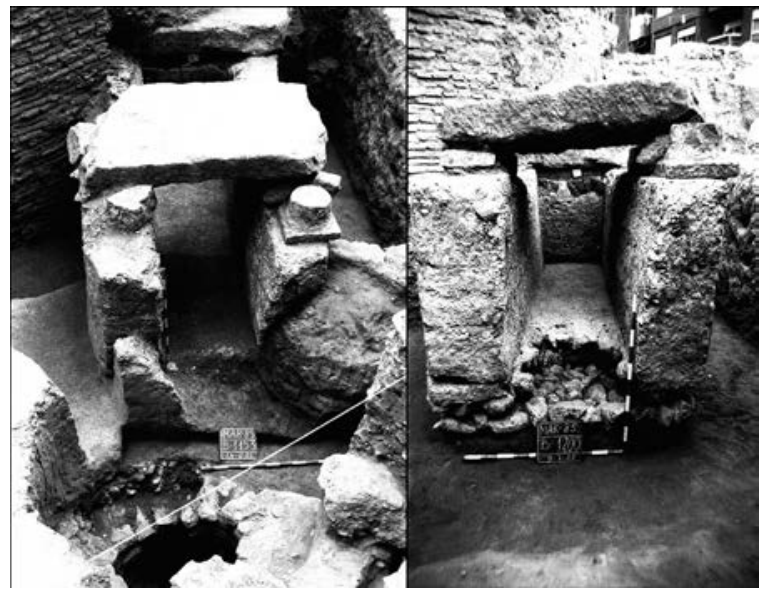

Fig. 3: Claveguera identificada en l'excavació del carrer del Mar núm 19.

majoritàriament entre les sigil·lades africanes, amb les produccions de TSA A $(10,1 \%)$, A/D $(0,7 \%)$ i C $(4,9 \%)$, en menor mesura la TSH $(3,1 \%)$ i les ceràmiques de parets fines $(1,4 \%)$. La resta de produccions de vaixella fina es poden considerar com a residuals. Les llànties suposen un $1,7 \%$; la ceràmica africana de cuina és la producció més abundant $(32,8 \%)$ junt amb la comuna oxidant $(24,7 \%)$ i la ceràmica regional reductora de cuina $(13,2 \%)$. Amb percentatges molt escassos apareixen la 


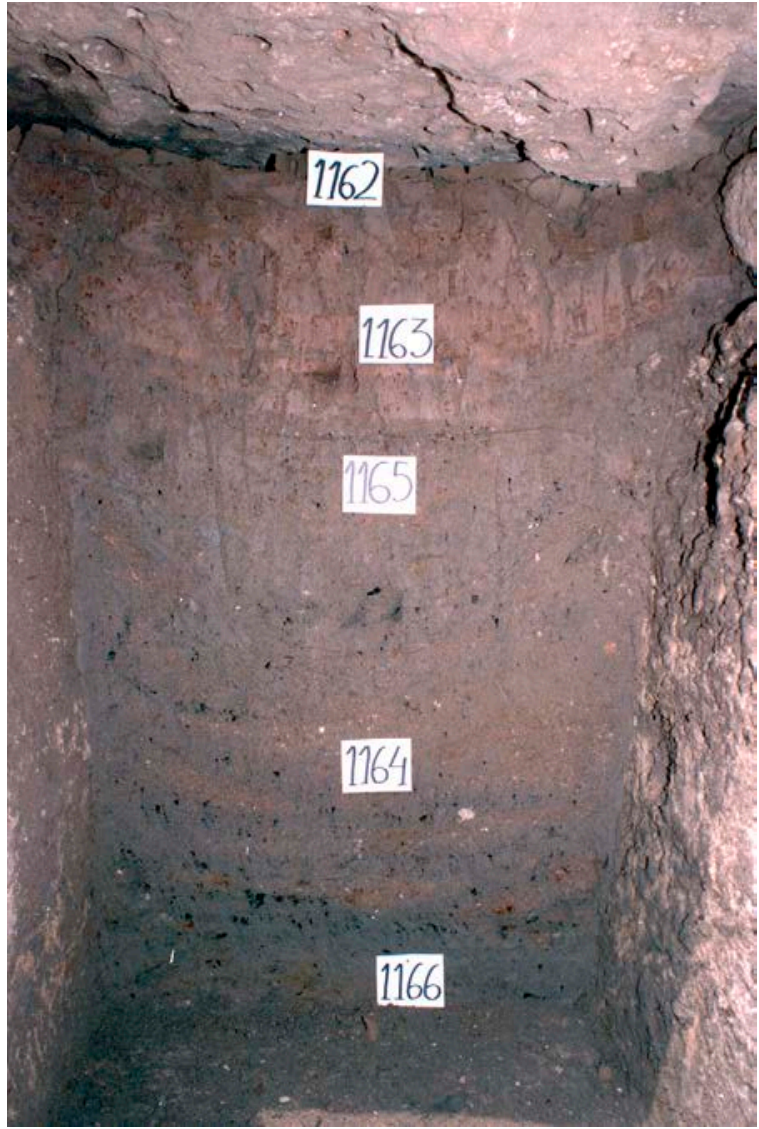

Fig. 4: Estrats de rebliment de l'interior de la claveguera.

ceràmica comuna africana $(0,3 \%)$, la ceràmica reductora de taula $(0,3 \%)$ i la ceràmica d'engalba roja pompeiana $(0,3 \%)$, també residual.

En la base de la cloaca es documentà una fina capa (UE 1166) de terra sorrenca de color marró de $10 \mathrm{~cm}$ de grossària. Era el primer estrat que se'n formà a l'interior, on es trobaren 35 peces ceràmiques. La vaixella fina era escassa però proporcionava una bona precisió cronològica. Estava formada, únicament per un plat de la forma 15/17 de TSH, un bol de TSA A de la forma Hayes 31 (fig. 7,2 ), que data de principi o mitjan del s. III, algun fragment de TSAA/D i dos fonts de la forma Hayes 50 de TSA C datades entre el 230/240 i el 325 d.C. (fig. 7, 1). La ceràmica africana de cuina comprén 11 individus que presenta una àmplia cronologia: la tapadora del tipus Òstia III, 332 cronològicament situada entre els flavis i el s. III (fig. 7, 5 i 6); les cassoles dels tipus Hayes 23 B (fig. 7, 3) i Òstia III, 267 (fig. 7, 7 i 8), que es daten entre el s. II i final del s. IV/inici del V; la font de la forma Hayes

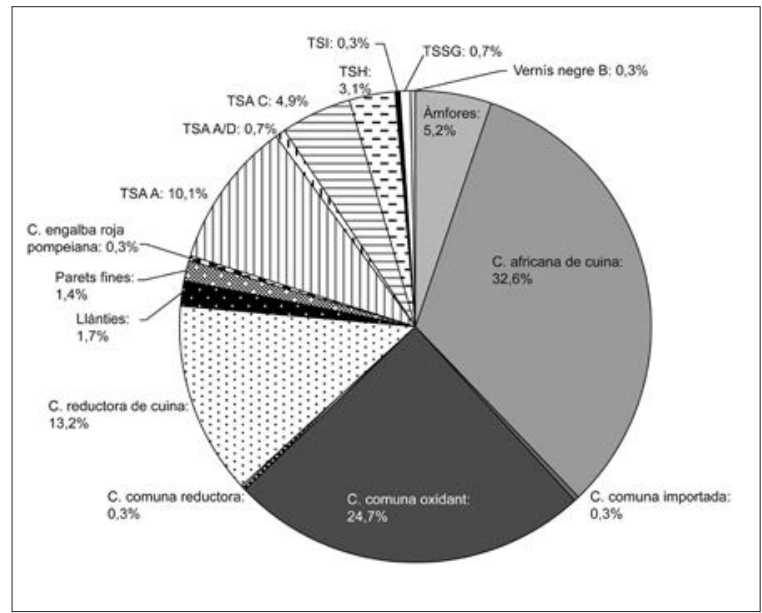

Fig. 5: Gràfic de les diferents produccions aparegudes a l'excavació.

181, del s. II al principi del V; i la tassa de la forma Hayes 131, de la segona meitat del s. II o principi del III (fig. 7, 4). No apareix ceràmica de cuina local o regional, però sí ceràmica comuna, majoritàriament oxidant (Escrivà 1995: 168), entre la qual predominen les formes tancades com gerres de la forma Gr. I Urceus (fig. 7, 9, 10, 11 i 13), ampolles de la forma Gr. II Lagoena i alfàbies de la forma Gr. VIII Aula/olla (fig. 7, 14). A més, hi ha dos recipients oberts del tipus Gr. IV.1 Paropsis (fig. 7, 12); un d'ells està complet, és de cos globular amb vora reentrant marcada per canaletes exteriors i presenta una ansa en forma de cinta lateral i un bec vessador de secció circular (fig. $7,15)$ que no apareix a la ciutat amb anterioritat a aquesta data (Huguet 2016: 507). Cal destacar l'aparició d'una gerra de ceràmica comuna reductora de taula, de la forma Gr. I Urceus. Pel que fa a les àmfores, són molt escasses $i$ es constata la presència de fragments d'àmfora itàlica $i$ una peculiar àmfora de tipus indeterminat amb cos globular, coll curt i vora amb motllura i anses arrodonides lleugerament elevades i de secció ovalada amb canaletes (fig. 7, 16). Tot i que no podem assegurar-ho, aquest gran contenidor recorda a les àmfores orientals procedents de Creta (AC2 i AC3) (Marangou-Lerat 1995: pl. XVIII, fig. 68 a) sobretot per la peculiar forma de les anses i la seua pasta; tanmateix, a l'inventari apareix com a àmfora indeterminada ja que no tenim la certesa de la seua procedència oriental.

Per damunt de la primera capa se'n trobà una altra (UE 1164) que mostrava una clara diferència amb la resta ja que estava composta de graveta molt fina (1 a $3 \mathrm{~mm}$ ), fragments ceràmics triturats i alguns nòduls de calç 
UNA MOSTRA DEL COL·LAPSE URBÀ A VALENTIA AL S. III D.C.: LES CERÀmiQUES ROMANES DEL CARRER DEL MAR NÚM. 19 (VALÈNCIA, ESPANYA)

\begin{tabular}{|c|c|c|c|c|c|c|c|}
\hline Producció/Tipologia & 1146 & 1162 & 1163 & 1164 & 1165 & 1166 & Total \\
\hline Àmfora africana & 1 & & & 1 & & & 2 \\
\hline Keay I B & & & & 1 & & & 1 \\
\hline Àmfora bètica & 2 & & & & & & 2 \\
\hline Beltrán II A & 1 & & & & & & 1 \\
\hline Dressel 20 & 1 & & & & & & 1 \\
\hline Àmfora hispànica & & & & 1 & & & 1 \\
\hline Dressel 2/4 & & & & 1 & & & 1 \\
\hline Àmfora indeterminada & & & 1 & 1 & 1 & & 3 \\
\hline Àmfora itàlica & 1 & & & & & 1 & 2 \\
\hline Indeterminada & & & & & & I & $\mathbf{1}$ \\
\hline Ȧmfora tarraconense & 3 & & & & & 1 & 4 \\
\hline Beltrán II B? & 1 & & & & & & 1 \\
\hline Dressel 2-3 & 1 & & & & & & 1 \\
\hline Galoise 4 & 1 & & & & & & 1 \\
\hline Àmfora tripolitana & & & & 1 & & & 1 \\
\hline Keay XXV & & & & 1 & & & 1 \\
\hline C. africana de cuina & 57 & & & 22 & 3 & 12 & 94 \\
\hline Atl. CVIII, 7 & & & & 1 & & & 1 \\
\hline H. 194/ O. II, 303 & 1 & & & & & & 1 \\
\hline Hayes 131 & 1 & & & & & 1 & 2 \\
\hline Hayes 181 & 3 & & & 1 & & 1 & 5 \\
\hline Hayes $23 \mathrm{~A}$ & 1 & & & & & & 1 \\
\hline Hayes $23 \mathrm{~B}$ & 10 & & & 4 & 1 & 2 & 17 \\
\hline Òstia 1, 261 & 15 & & & 6 & & & 21 \\
\hline Òstia I, 262 & 3 & & & & & & 3 \\
\hline Òstia I, 269 & 1 & & & & & & 1 \\
\hline Òstia I, 273 & 3 & & & & & & 3 \\
\hline Òstia III, 267 & 17 & & & 4 & 1 & 2 & 24 \\
\hline Òstia III, 332 & 2 & & & 6 & & 6 & 14 \\
\hline Uzita 48.1 & & & & & 1 & & 1 \\
\hline C. comuna importada & 1 & & & & & & 1 \\
\hline Comun tipo $21 \mathrm{~A}$ & 1 & & & & & & 1 \\
\hline C. comuna oxidant & 42 & & & 9 & 6 & 14 & 71 \\
\hline Gr. I Urceus & 19 & & & 4 & 1 & 6 & 30 \\
\hline Gr. II Lagoena & 3 & & & & & 1 & 4 \\
\hline Gr. III Calix & & & & 1 & & & 1 \\
\hline Gr. IV.1 Paropsis & 16 & & & & & 3 & 19 \\
\hline Gr. V Mortarium & 1 & & & 3 & & & 4 \\
\hline Gr. VII Pelvis & 3 & & & 1 & & & 4 \\
\hline Gr. VIII Aula/olla & & & & & & 1 & 1 \\
\hline Indeterminada & & & & & 5 & 3 & 8 \\
\hline C. comuna reductora & & & & & & 1 & 1 \\
\hline Gr. I Urceus & & & & & & 1 & 1 \\
\hline
\end{tabular}




\begin{tabular}{|c|c|c|c|c|c|c|c|}
\hline Producció/Tipologia & 1146 & 1162 & 1163 & 1164 & 1165 & 1166 & Total \\
\hline C. reductora de cuina & 28 & & & 9 & 1 & & 38 \\
\hline ERW 1.1 & 3 & & & 1 & & & 4 \\
\hline ERW 1.2 & 8 & & & 2 & & & 10 \\
\hline ERW 1.3 & 8 & & & 2 & & & 10 \\
\hline ERW 1.4 & 2 & & & 1 & & & 3 \\
\hline ERW 1.7 & 3 & & & 1 & & & 4 \\
\hline ERW 1.8 & 3 & & & 1 & & & 4 \\
\hline Cassola & 1 & & & 1 & & & 2 \\
\hline Indeterminada & & & & & 1 & & 1 \\
\hline Ferro & & & & 1 & 3 & 3 & 7 \\
\hline Claus & & & & & 3 & 3 & 6 \\
\hline Escòria & & & & 1 & & & 1 \\
\hline Llànties & 3 & & & 2 & & & 5 \\
\hline Dressel 20 & 1 & & & & & & 1 \\
\hline Dressel 28 & & & & 2 & & & 2 \\
\hline Indeterminada & 2 & & & & & & 2 \\
\hline Material de construcció & & & & 1 & & & 1 \\
\hline Parets fines llises & 1 & & & 1 & 2 & & 4 \\
\hline Indeterminada & & & & 1 & 2 & & 3 \\
\hline Rubielos de Mora 2.1 & 1 & & & & & & 1 \\
\hline C. Engalba roja pompeiana & 1 & & & & & & 1 \\
\hline R-pomp. 28 o 33 & 1 & & & & & & 1 \\
\hline TSA A & 22 & & & 5 & 1 & 1 & 29 \\
\hline Hayes 121 o 126 & 1 & & & & & & 1 \\
\hline Hayes 17 & 3 & & & & & & 3 \\
\hline Hayes 22 & 1 & & & & & & 1 \\
\hline Hayes 27 & 4 & & & 1 & & & 5 \\
\hline Hayes 3 & 1 & & & 1 & & & 2 \\
\hline Hayes $3 \mathrm{~A}$ & 1 & & & & & & 1 \\
\hline Hayes 31 & 7 & & & 3 & & 1 & 11 \\
\hline Hayes $6 \mathrm{C}$ & 2 & & & & & & 2 \\
\hline Hayes 8 & 1 & & & & & & 1 \\
\hline Hayes 9 & 1 & & & & & & 1 \\
\hline Indeterminada & & & & & 1 & & 1 \\
\hline TSA A/D & 1 & & & & & 1 & 2 \\
\hline Hayes 32 & 1 & & & & & & 1 \\
\hline Indeterminada & & & & & & 1 & 1 \\
\hline TSAC & 8 & & 1 & 2 & 3 & 2 & 14 \\
\hline Hayes 44 o 45 & 1 & & & & & & 1 \\
\hline Hayes $48 \mathrm{~A}$ & & & & & 1 & & 1 \\
\hline Hayes 50 & 6 & & 1 & 2 & 2 & 2 & 13 \\
\hline Hayes $53 \mathrm{~B}$ & 1 & & & & & & 1 \\
\hline
\end{tabular}




\begin{tabular}{|l|c|c|c|c|c|c|c|}
\hline \multicolumn{1}{|c|}{ Producció/Tipologia } & 1146 & 1162 & 1163 & 1164 & 1165 & 1166 & Total \\
\hline TSH & $\mathbf{6}$ & & & 1 & & 2 & 9 \\
\hline Forma 15/17 & & & & & & 1 & 1 \\
\hline Forma 27 & 1 & & & & & & 1 \\
\hline Forma 37 & 1 & & & & & & 1 \\
\hline Forma 8 & 1 & & & & & & 1 \\
\hline Hispànica 1 & & & & 1 & & & 1 \\
\hline Indeterminada & 3 & & & & & 1 & 4 \\
\hline TSI & $\mathbf{1}$ & & & & & & 1 \\
\hline TSSG & $\mathbf{1}$ & & & 1 & & & 2 \\
\hline Vernís negre B & $\mathbf{1}$ & & & & & & 1 \\
\hline Vidre & $\mathbf{2}$ & & & & & & 2 \\
\hline Total general & & & & & & & 288 \\
\hline
\end{tabular}

Fig. 6 (ve de les pàgines anteriors): Resum de l'inventari ceràmic, per UUEE.

barrejats amb altres terrossos de terra solta de color verdós. Aquesta unitat presentava una potència de $50 \mathrm{~cm}$, és a dir, ocupava quasi la meitat inferior de la cloaca. En general, el material ceràmic augmentava en nombre quan més s'aprofundia en la capa. En aquesta unitat es recuperaren 56 peces ceràmiques. La vaixella fina no és abundant i, probablement, la TSSG i la TSH de la forma 1 (fig. $8,3)$ s'han de considerar com a residuals. Hi ha TSA A en les seues formes més tardanes, Hayes 3 (fig. 8, 1 i 2), 27 i 31; i TSA C, amb una font de la forma Hayes 50 (fig. 8 , 4). A més, s'han documentat una copa de ceràmica de parets fines i una llàntia africana del tipus Dressel 28 (fig. 8,5 i 6 ) amb bec en forma de cor i profusament decorada, que cronològicament s'emmarca entre els ss. II i III. Les ceràmiques africanes de cuina són molt abundants, ja que representen quasi el 50\% del total de ceràmiques de la unitat. Les formes majoritàries són la tapadora amb les variants altimperials Òstia III, 332 (fig. 8, 11 i 12) i Òstia I, 261 (fig. 8, 14), i les cassoles dels tipus Òstia III, 267 (fig. 8, 13) i Hayes 23 B (fig. 8, 7 i 8). A més, hi ha una font de la forma Hayes 181 (fig. 8,9) i una cassola de la primera meitat del s. III de la forma Atlante CVIII, 7 (Tortorella 1981: 221) (fig. 8, 10). La ceràmica reductora de cuina alt imperial està representada en les seues formes més freqüents (Reynolds 1993; Huguet 2012): cassoles de llavi engrossit del tipus ERW 1.1 (fig. 8, 15); olles amb coll del tipus ERW 1.2 (fig. 8, 6 i 17), i sense coll del tipus ERW 1.3 (fig. 8, 18 i 19); olletes del tipus ERW 1.4 (fig. 8, 20); tapadores del tipus ERW 1.7 (fig. 8 , 21); i gerres del tipus ERW 1.8. Entre la ceràmica comuna de cocció oxidant hi ha sobretot gerres de la forma Gr. I Urceus (fig. 8, 22, 23, 24 i 25) i morters de la forma Gr. V Mortarium (fig. 8, 26, 27 i 28), una pelvis Gr. VII Pelvis (fig. 8, 29) i també una copa o bol de la forma Gr. III Calix (fig. 8,30). A més a més, hi ha àmfores tarraconenses del tipus Dressel 2/4, africanes del tipus Keay I B (fig. 8,32) i tripolitanes del tipus Keay XXV (fig. 8, 31).

Les dues capes descrites ocupaven ja la meitat de l'espai interior de la claveguera, mentre que l'espai superior estava ocupat per altres tres nivells arqueològics.

Per sobre dels dos primers nivells, es trobava un estrat d'argila de color gris obscur (UE 1165) en el qual abundaven les restes orgàniques, majoritàriament fragments grans de carbó, restes de fauna i malacologia, sobretot caragols. A mesura que s'aprofundia, la capa s'anava fent menys compacta fins a assolir una grossària de $30 \mathrm{~cm}$. Pel que fa al material ceràmic, es documentaren fragments de tegulae i morter, però destacaven les ceràmiques africanes de cuina i TSA $\mathrm{C}$ a partir de les quals es pogué datar el conjunt. Es tractava de 17 individus que han aportat una interessant precisió cronològica. Junt a alguns fragments de ceràmiques de parets fines, TSH i TSA A, apareix una font de TSA C de la forma Hayes 48 (fig. 9, 1), datada entre el 220 i 270 d.C., i dues de la forma Hayes 50 (fig. 9, 2). Les ceràmiques africanes de cuina són escasses, i entre elles es troben les cassoles clàssiques de les formes Hayes 23 B (fig. 9, 3) i Òstia III, 267 i la gerra del tipus Uzita 48.1 que es data entre els ss. II i III d.C. Es trobaren alguns fragments informes de ceràmica reductora de cuina altimperial i de ceràmica 
Esperança Huguet Enguita

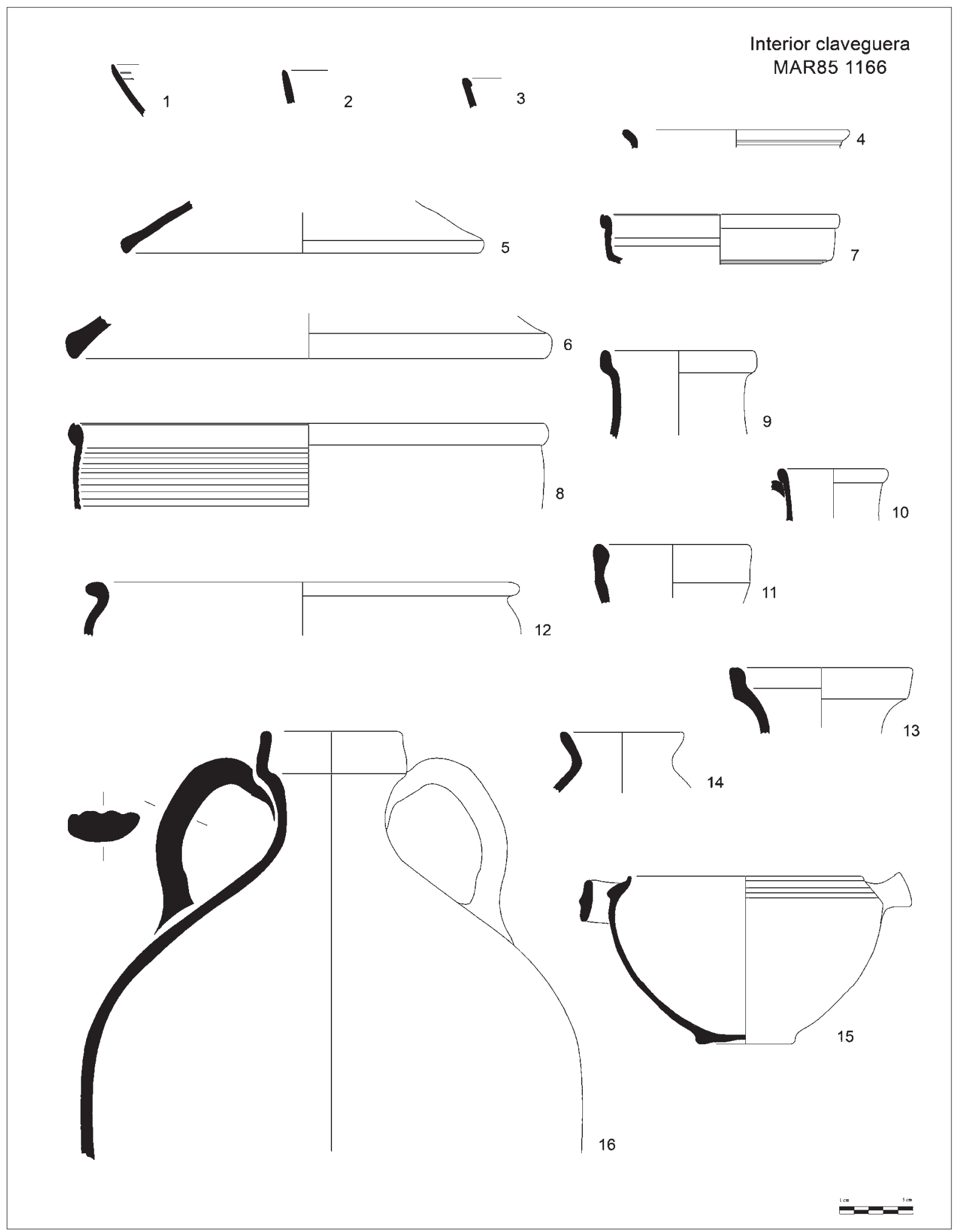

Fig. 7: Ceràmiques de l'interior de la claveguera (UE 1166): 1-2, TSA C i A; 3-8, Ceràmica africana de cuina; 9-15, Ceràmica comuna de cocció oxidant; 16, Àmfora tarraconense.

204 


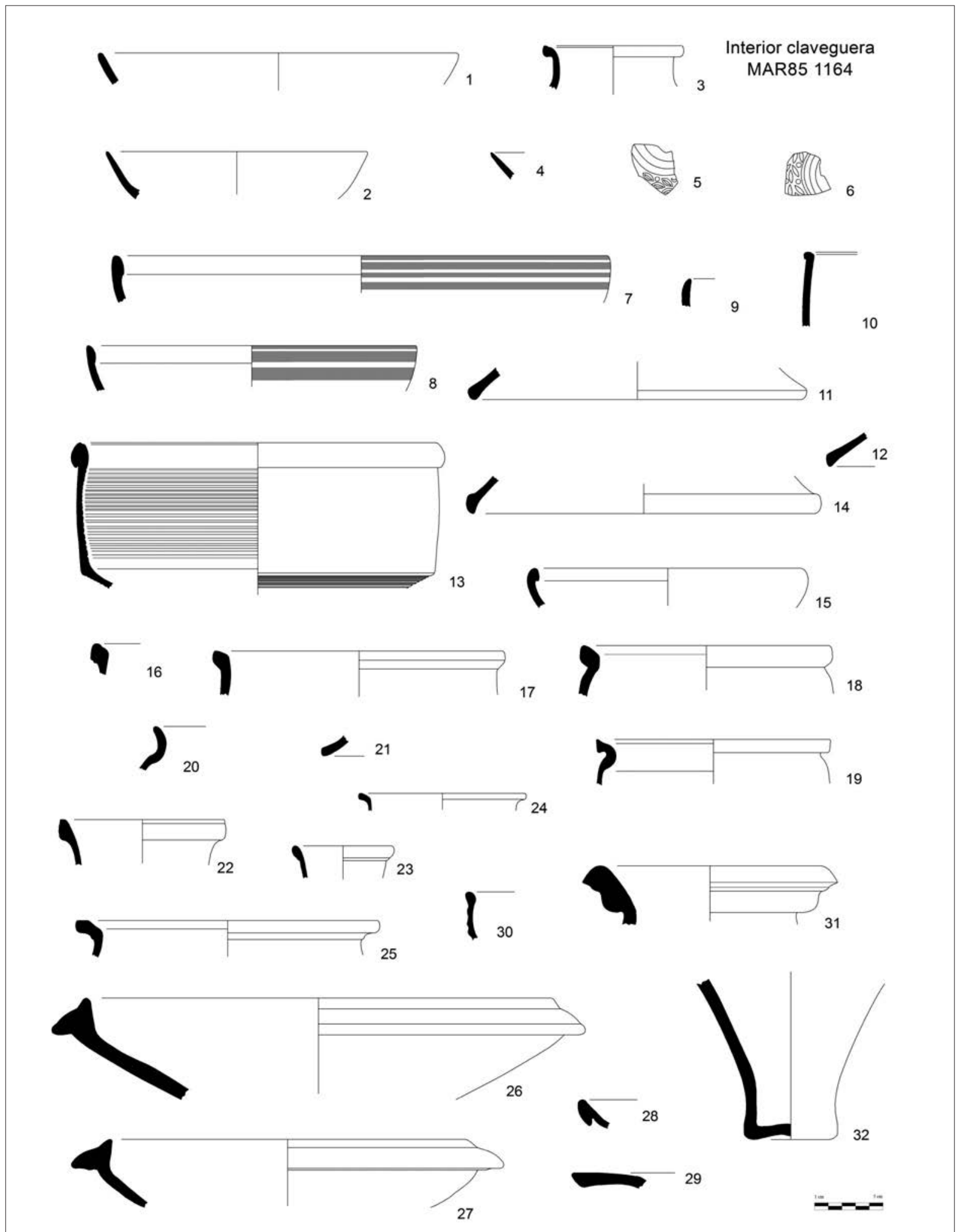

Fig. 8: Ceràmiques de l'interior de la claveguera (UE 1164): 1-4, Vaixella fina; 5 i 6, Llànties; 7-14, Ceràmica africana de cuina; 15-21, Ceràmica reductora de cuina regional; 22-30, Ceràmica comuna de cocció oxidant; 31-32, Àmfores africanes. 


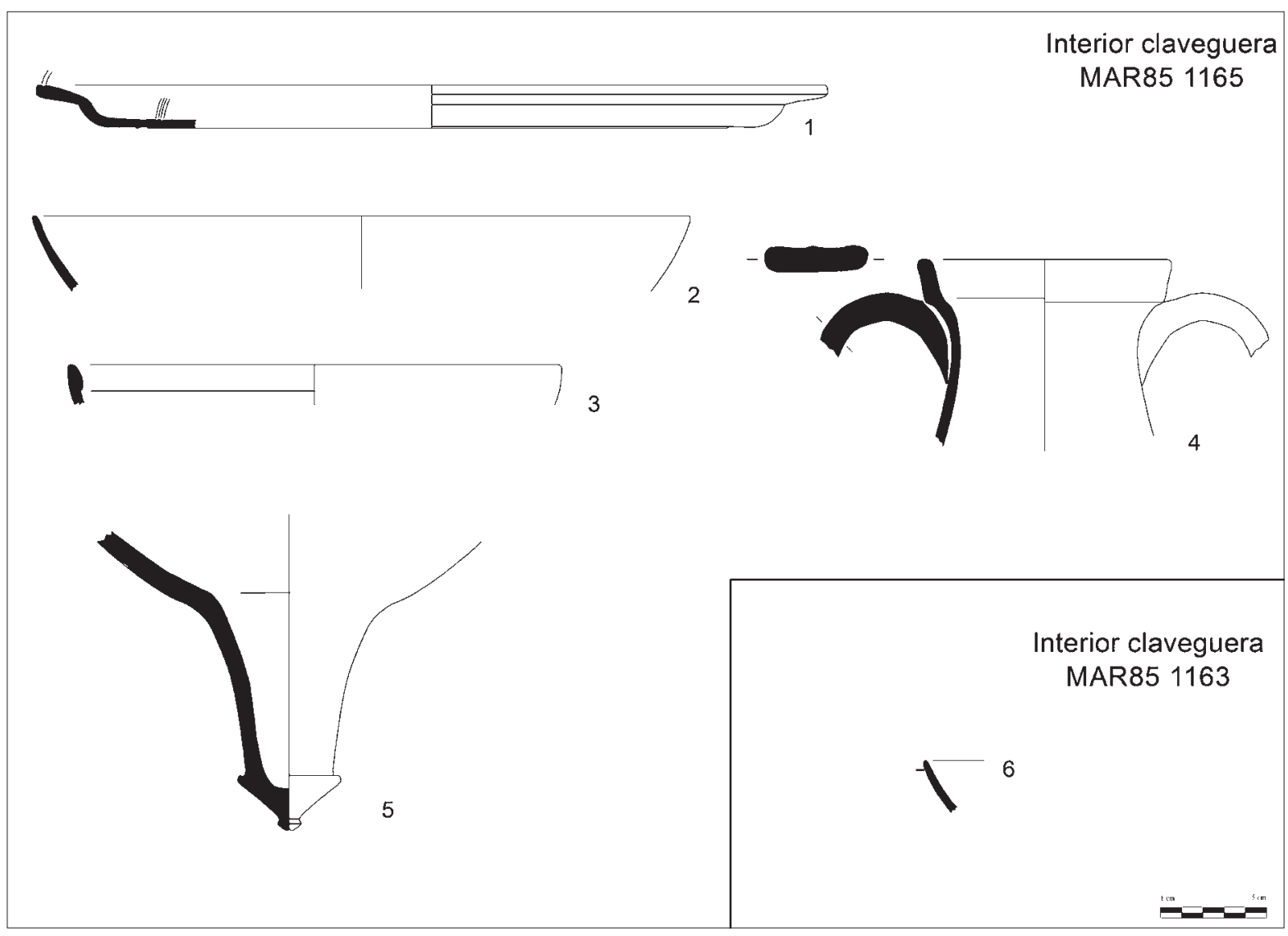

Fig. 9: Ceràmiques de l'interior de la claveguera (UUEE 1165 i 1163): 1-2, TSA C; 3, Ceràmica africana de cuina; 4, Ceràmica comuna de cocció oxidant; 5, Àmfora; 6, TSA.

comuna oxidant, entre la qual únicament s'ha identificat una gerra de la forma Gr. I Urceus (fig. 9, 4). Per últim, s'han documentat fragments d'àmfores indeterminades (fig. 9, 5).

Per sobre, ja en la part alta de la claveguera, s'estenia una capa d'argila rogenca (UE 1163) prou compacta que tenia una grossària de $30 \mathrm{~cm}$ en la part central, amb abundants restes de residus orgànics, probablement arrels descompostes, que tenien forma de filaments obscurs. Es trobaren escassos fragments ceràmics: una font de TSAC de la forma Hayes 50 (fig. 9, 6), a més de fragments indeterminats de ceràmica comuna oxidant i d'àmfora.

En la capa superior, immediatament per sota de les lloses i en contacte amb aquestes, hi havia una fina capa d'argila de color beix (UE 1162) que es degué formar per decantació en ambient líquid. Era l'últim estrat que reblia la cloaca i només contenia ceràmica comuna oxidant indeterminada.
A l'extrem NE la cloaca quedava interrompuda, com tallada probablement des d'antic, no sabem si per desguassar a un barranc o si en algun moment anava més enllà. Durant l'excavació es documentà un estrat (UE 1146) que eixia de la cloaca i es corresponia a les UUEE 1164 i 1166 pel que fa a altura i composició i estava format per les restes que vessaven de la cloaca en finalitzar aquesta i que s'acumularen en la boca. El material ceràmic que s'hi trobà és molt semblant al de les capes 1164 i 1166, però amb la peculiaritat que hi ha diverses peces completes. L'últim estrat que s'ha estudiat és la UE 1146, que contenia el material que caigué a l'exterior de la cloaca. Era un estrat amb molt de material, 180 peces, de les quals en destaquen algunes senceres. Açò demostra que la força i la quantitat d'aigua que discorria per la claveguera era suficient per a poder arrossegar recipients $i$ contenidors de mesura mitjana o petita com llànties, gerres i ampolles. 
Pel que fa a la vaixella fina s'han documentat fragments indeterminats de ceràmica de vernís negre, TSI i TSSG, d'aquesta també marmorata, que es deuen considerar com a residuals. Probablement també ho són, en aquest context, algunes de les peces de TSH, com les copes de la forma 8 (fig. 10, 1) i 37 (fig. 10, 2), i les primeres formes de TSA A dels tipus Hayes 3A, 8 (fig. 10, 3), 9, 22 (fig. 10, 4) i 121 o 126. Les formes de TSA A tardanes són abundants, sobretot les de final del s. II i principi del III: Hayes 6C (fig. 10, 5), 17 (Fig. 10, 6 i 7), 27 (fig. $10,8,9$ i 10); però també les formes de principi i mitjan del III d.C.: Hayes 31 (fig. 10, 11). Per sota d'aquestes formes, quantitativament parlant, es troba la TSA A/D amb la forma Hayes 32 (fig. 10, 12) que és coetània de les anteriors o lleugerament posterior. La TSA C està ben representada però amb una varietat formal escassa: un fragment de la forma Hayes 44 o 45 i sis fonts de la forma Hayes 50, datades entre el 230/240 i 325 (fig. 10, 13 i 14). Per últim, hem d'afegir el que considerem una intrusió: un fragment de base d'una font de la forma Hayes 53 (fig. $10,15)$ en TSA C que és pròpia del s. IV.

Sense deixar la vaixella fina només queda esmentar l'aparició d'algunes copes de ceràmica de parets fines, en concret una forma Rubielos de Mora 2.1 (fig. 10, 16), tan habitual a la ciutat de Valentia entre l'època d'Adrià i el final del s. II (Huguet i Ribera 2014: 161). Pel que fa a les llànties, majoritàriament són d'origen africà, i entre elles se n'han documentat una del tipus Dressel 20 (fig. 10, 17) sense decoració i d'altres fragments corresponents a quatre individus més. Un d'aquests presenta en la base un segell dividit en dues línies il-legibles PV[-] i AE[-] (fig. 10, 18).

Entre la ceràmica importada de cuina hi ha un fragment de font d'engalba roja pompeiana, del tipus Rpomp. 28 o 33, de la Campània, que s'ha considerat com a residual. Tanmateix, l'aclaparadora majoria de ceràmica de cuina és africana: hi ha formes flàvies i del s. II: cassoles dels tipus Hayes 23 A, Hayes 194/Òstia II, 303 (fig. 10, 19) i tapadores Òstia III, 332 (fig. 10, 20), però les formes més abundants són les que apareixen a partir de la segona meitat del s. II o l'època dels Severs: cassoles de les formes Hayes 23 B (fig. 10, 21 i 22), Òstia III, 267 (fig. 10, 23 i 24), Òstia I, 273 (fig. 10, 25), Òstia I, 269 (fig. 10, 26) i Hayes 181; les tapadores dels tipus Òstia I, 261 (fig. 10, 27 i 28) i Òstia I, 262 (fig. 10, 29 i 30); i una tassa de la forma Hayes 131 . També africà és un gran bací o gibrell de pasta molt porosa i groga que probablement tindria un ús no culinari. Es tracta de la forma Uzita 2, o bé el tipus 21A de Bonifay (2004: 262) amb grans parets verticals que s'exvasen a la part alta marcada a l'interior per una carena (fig. 11, 1), que es produeix al final del s. II i fins a mitjan del III d.C. És una forma esporàdicament exportada com prova aquesta troballa.

La ceràmica reductora de cuina altimperial és abundant $\mathrm{i}$ està ben representada en les formes clàssiques $i$ també en alguna d'excepcional. Es tracta de 27 individus entre els quals destaquen les olles amb i sense coll dels tipus ERW 1.2 (fig. 11, 4 i 5) i ERW 1.3 (fig. 11, 6 i 7), respectivament; l'olleta sense restes de foc de la forma ERW 1.4 (fig. 11, 8); les tapadores de la forma ERW 1.7; les cassoles de la forma ERW 1.1 (fig. 11, 3) i les gerres de la forma ERW 1.8. Entre les cassoles sorprèn l'aparició d'un exemplar sense graó intern que és el tret formal típic d'aquestes cassoles (fig. 11, 1). Un recipient molt semblant aparegué als estrats de la claveguera, però és una forma poc freqüent en l'estratigrafia de la ciutat. Per últim, cal destacar l'aparició d'una ampolla de coll estret tampoc documentada fins al moment a Valentia. Es tracta, probablement, d'una variació tardana de la forma ERW 1.8, però amb modificacions respecte al model alt imperial (fig. 11, 9). La pasta és la típica descrita per Reynolds (1993: 95), però l'ampolla presenta un panxa baixa amb coll estret $\mathrm{i}$ una ansa no funcional amb decoració helicoïdal enganxada sobre l'ansa funcional. Pel que fa a la datació, l'hem de situar al s. III a l'espera que altres contexts puguen aportar més llum sobre la seua cronologia, i tenint en compte que el desplaçament de la zona més ampla de la panxa cap a la meitat inferior s'ha documentat a la ciutat a mitjan del s. III d.C. (Huguet 2016: 560).

El grup de ceràmica comuna de cocció oxidant és considerable, amb 37 individus, entre els quals destaquen majoritàriament gerres i gibrells. Hi ha 22 formes tancades de les quals 19 són gerres del tipus Gr. I Urceus i les altres tres són ampolles del tipus Gr. II Lagoena. Entre les primeres apareixen les variants de segles anteriors amb motllura i graó intern per a tapadora (fig. 11, 10, 11 i 12) i motllura doble amb o sense graó intern (fig. 11, 13 i 14), però ara apareixen formes evolucionades que tendeixen a la desaparició del graó intern (fig. 11, 15), als colls amples (fig. 11, 16 i 17) i vora vertical arrodonida a l'exterior (fig. 11, 18 i 19). Aquesta evolució inclou també el desplaçament del diàmetre major des de la part central a la part més baixa, com s'observa en l'exemplar de gerra de boca trilobulada que aparegué complet en aquesta 


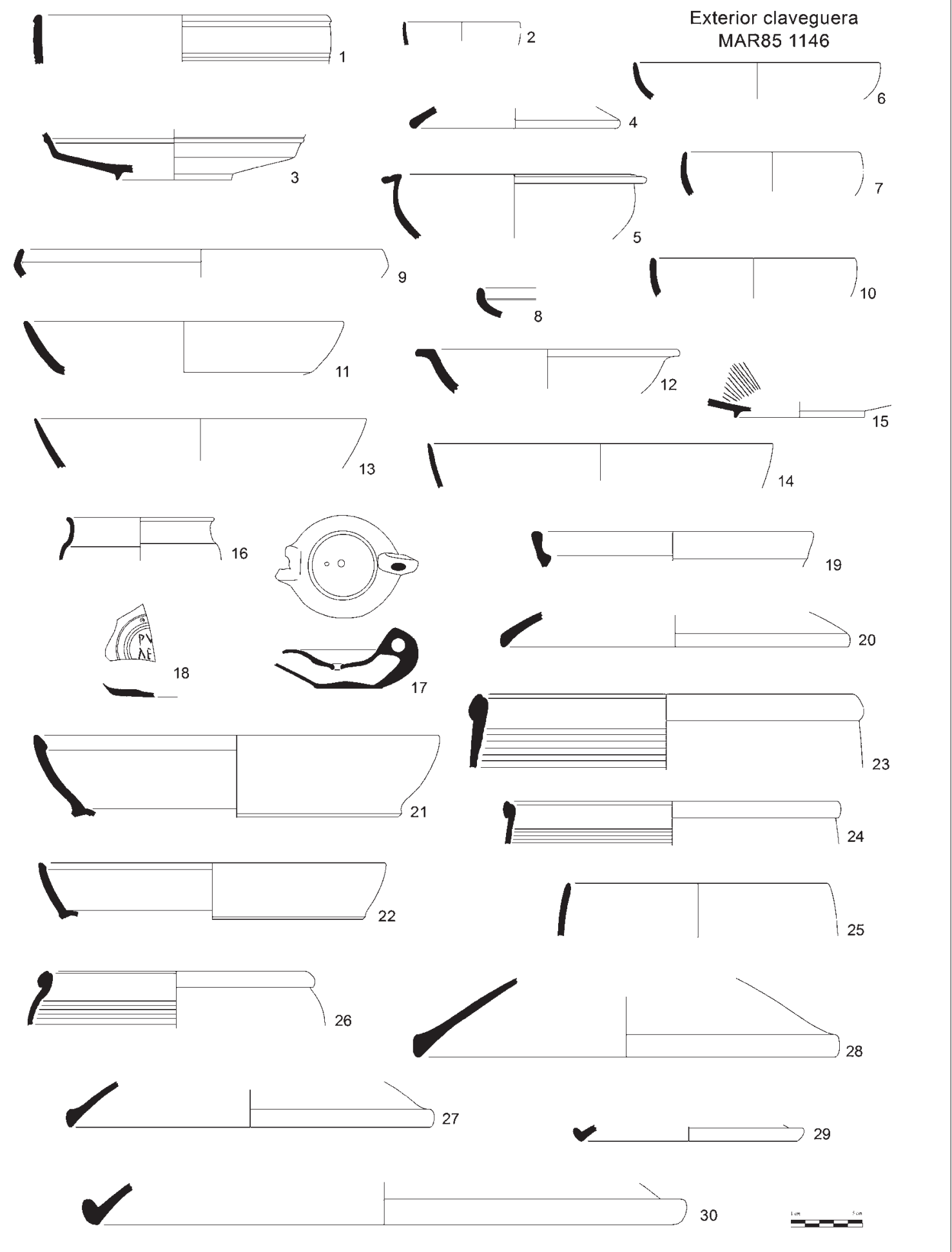

Fig. 10: Ceràmiques del desguàs (UE 1146): 1-18, Vaixella fina; 19-30, Ceràmica africana de cuina. 


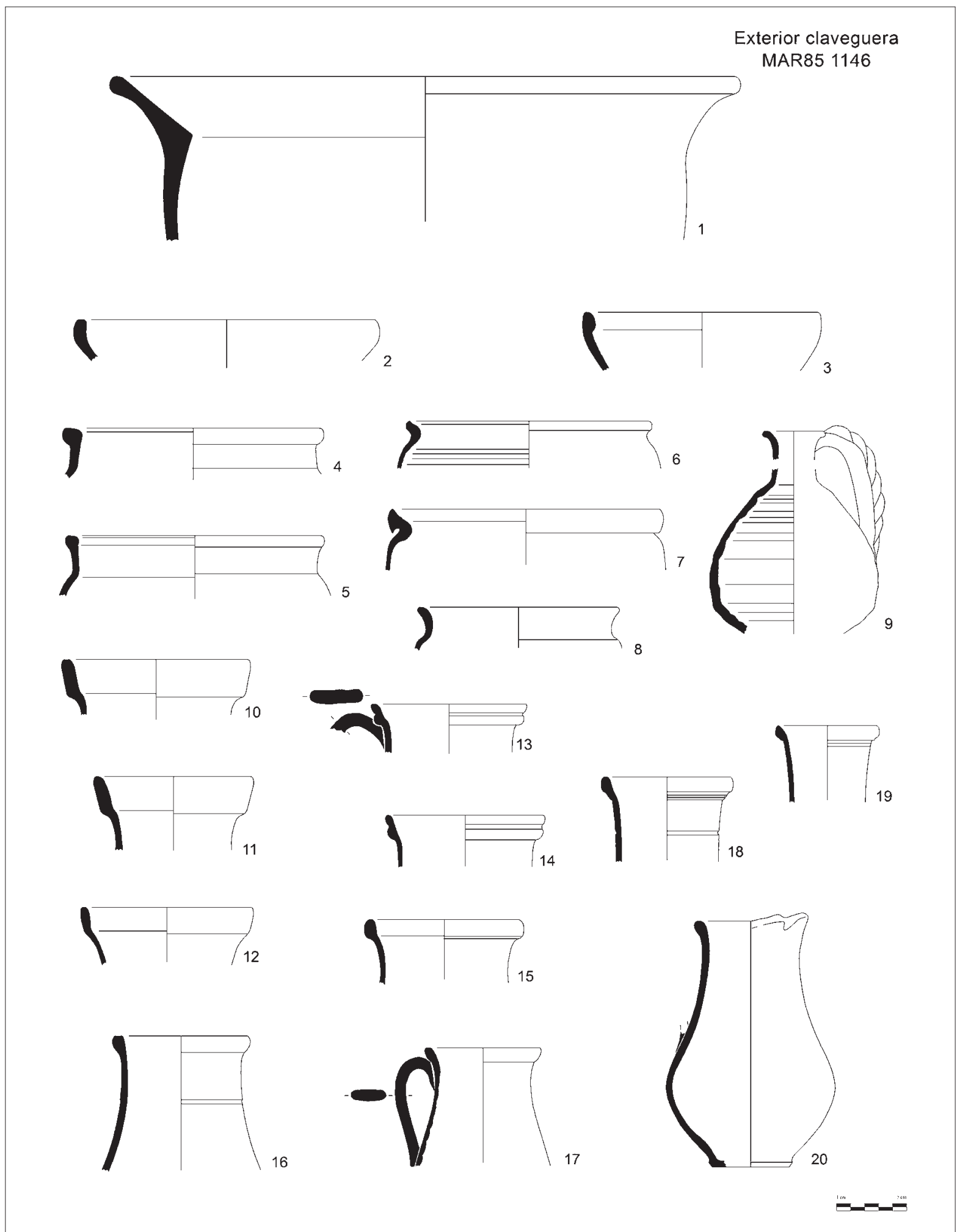

Fig. 11: Ceràmiques del desguàs (UE 1146): 1, Ceràmica comuna africana; 2-9, Ceràmica reductora de cuina regional; 10-20, Ceràmica comuna de cocció oxidant. 

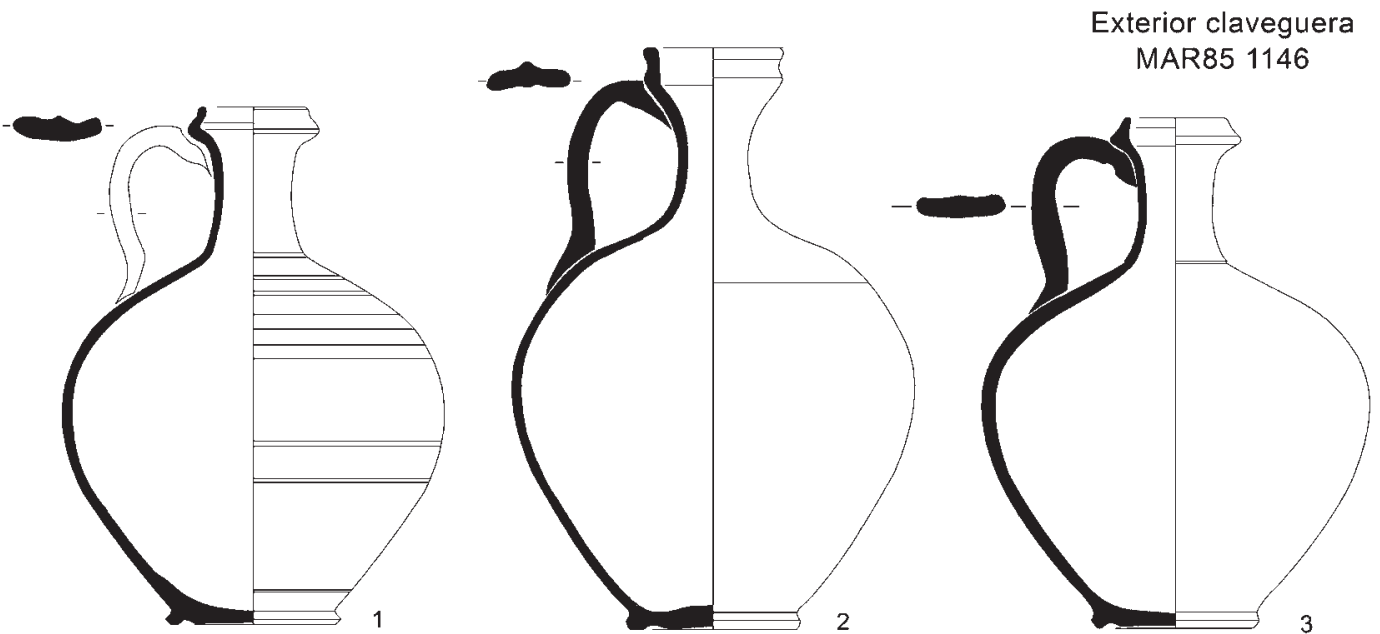

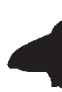
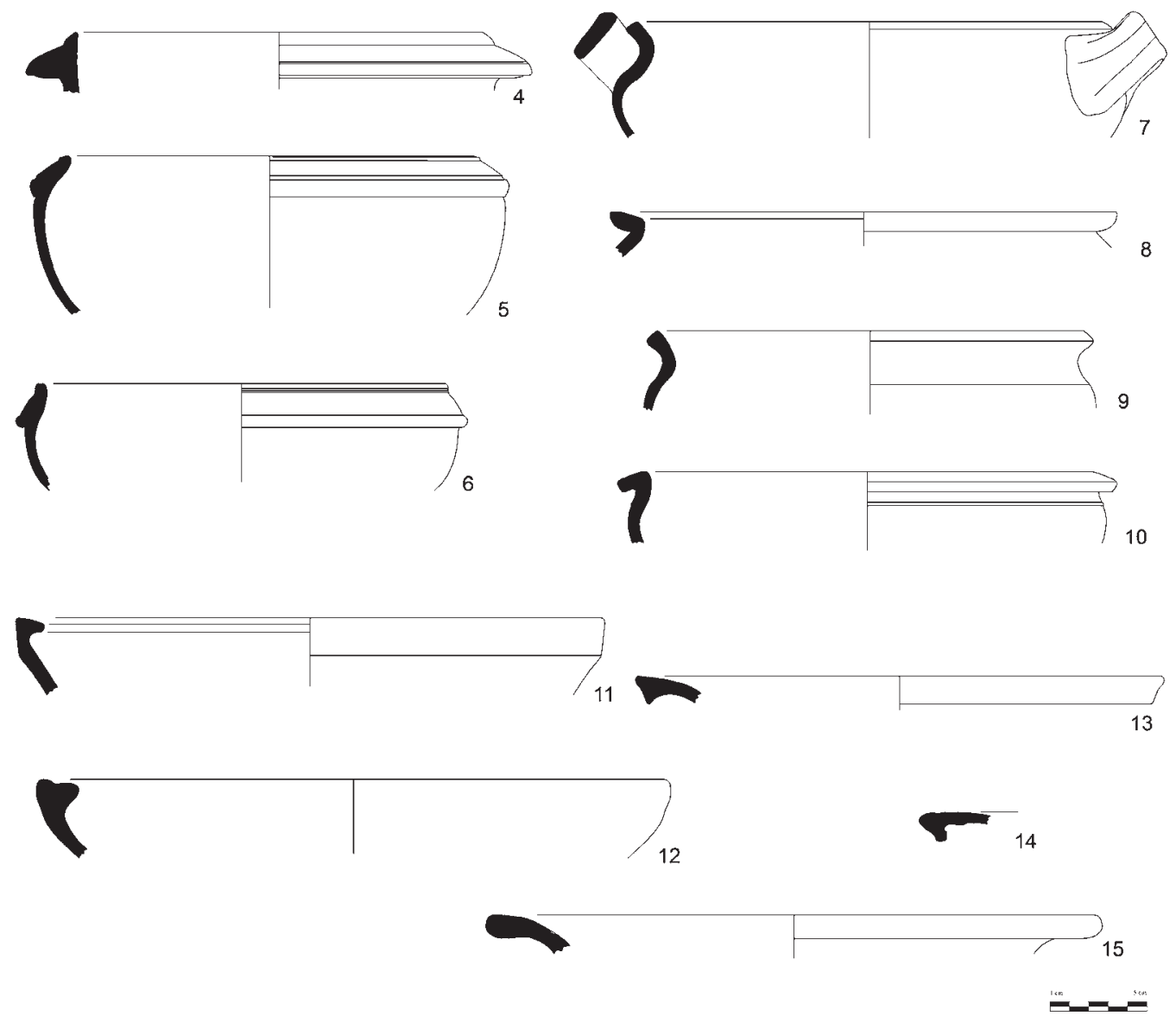

Fig. 12: Ceràmica del desguàs (UE 1146): Ceràmica comuna de cocció oxidant. 


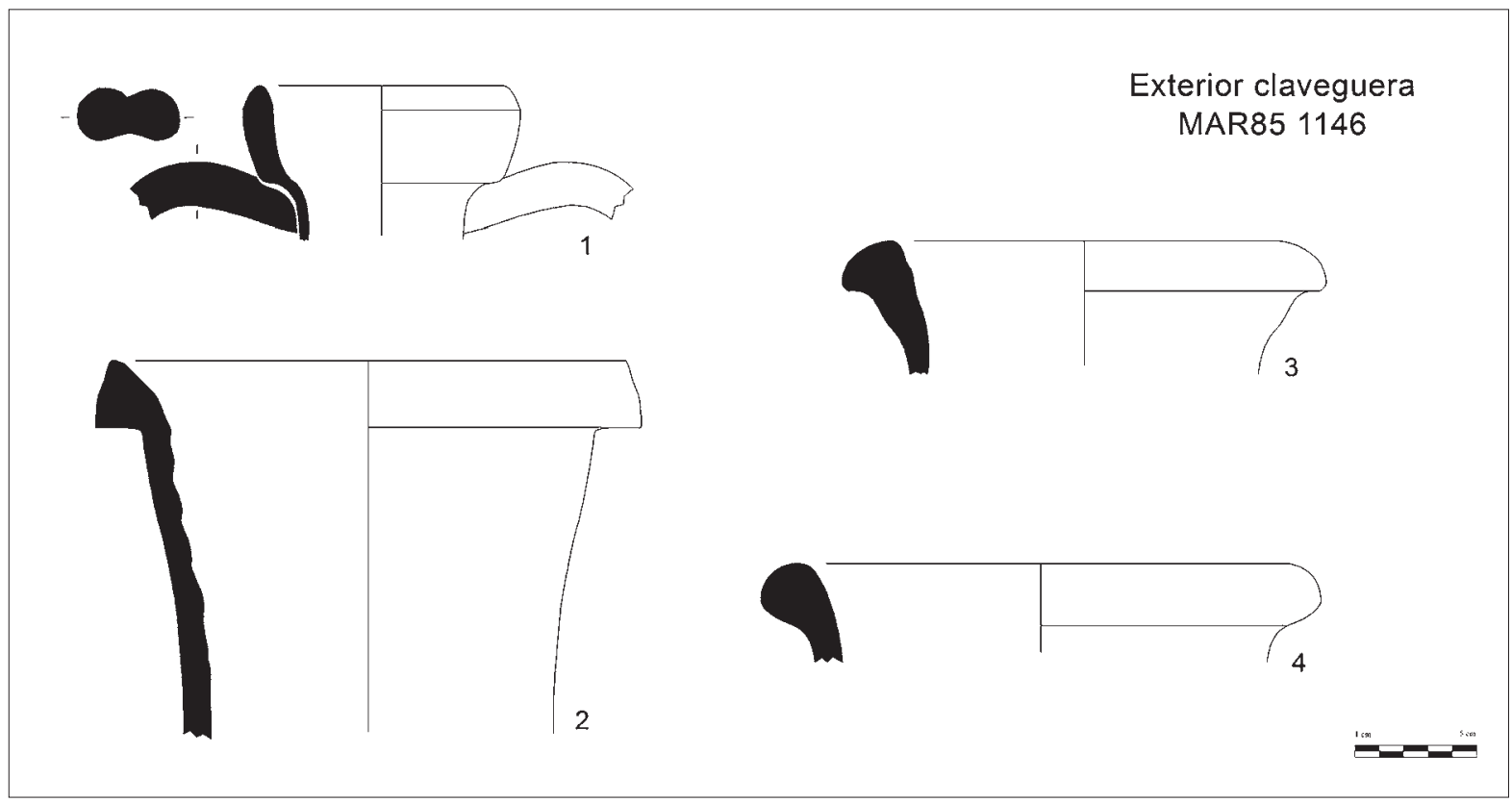

Fig. 13: Ceràmiques del desguàs (UE 1146): Àmfores.

unitat (fig. 11, 20) (Huguet 2016: 494). Les ampolles documentades són tres exemplars complets de Gr. II Lagoena (fig.12, 1, 2 i 3) amb cos, panxa alta, coll alt i estret amb motllura a la vora $\mathrm{i}$ ansa en forma de cinta. Entre els recipients oberts hi ha un morter de vora triangular (fig. 12,4) i 15 grans recipients oberts del tipus bol o fruiter, de la forma Gr. IV.1 Paropsis, entre els quals podem diferenciar quatre classes: amb vora reentrant $\mathrm{i}$ motllura amb canaletes a l'exterior (fig. 12, 5 i 6); amb perfil en "S" i vora exvasada (fig. 12, 7, 8 i 9); amb ala voltejada a l'exterior que s'assembla molt a un lebes (fig. 12, 10); i per últim, recipients més baixos amb carena alta i vora reentrant a cavall entre la Paropsis i el Lanx (fig. 12, 11 i 12). També hi ha tres vores d'ala horitzontal de recipients d'ús domèstic, del tipus Gr. VII Pelvis (fig. 12, 13, 14 i 15).

El grup de les àmfores és escàs, cosa lògica si tenim en compte les dimensions que poden tenir les àmfores. Tanmateix tenim un nombrós grup de pastes de diferents procedències: itàliques, africanes, però sobretot, tarraconenses i bètiques, a més d'alguns fragments d'àmfores indeterminades. Entre les tarraconenses s'han identificat dues del tipus Galoise 4 (fig. 13, 1), una Dressel 2/4, i una possible imitació de Beltrán IIB (fig. 13, 2). Entre les àmfores bètiques hi ha una Beltrán IIA (fig. 13, 3) i una Dressel 20 (fig. 13, 4).

\section{CONCLUSIONS}

Vista la varietat de material ceràmic procedent de l'amortització de la cloaca, podem establir una cronologia de mitjan del s. III per a l'inici del taponament. Probablement, el rebliment s'allargués durant tota la segona meitat del III mentre estava en ús, però ja sense manteniment ni neteja quan portava aigües residuals que arrossegaven, entre altres, aquests materials ceràmics. Aquest taponament es produí per un procés d'acumulació natural degut a l'arrossegament i decantació de les aigües que circulaven per l'interior de l'estructura, per aquesta manca de manteniment. Però, a més, és una mostra de l'ús de les clavegueres com a femer per a desfer-se de les deixalles. El que sembla indubtable és que els últims estrats, els situats a major altura, que taponen la totalitat de la claveguera, daten de la segona meitat del s. III d.C.

La mateixa cronologia presenta l'estrat que s'ha interpretat com el desguàs de la cloaca que, probablement, desembocava en un barranc. Aquest conté algunes peces de TSH que presenten perfils evolucionats, lluny de les formes clàssiques, $\mathrm{i}$ que són més exvasades $\mathrm{i}$ obertes $\mathrm{i}$ podrien datar-se cap a l'inici del s. III. Amb tot i això, no s'han documentat formes hispàniques pròpies de la producció avançada (circa 250-circa 330) o tardanes (circa 330-circa 380) (Paz Peralta 2008: 506). Hi ha també 


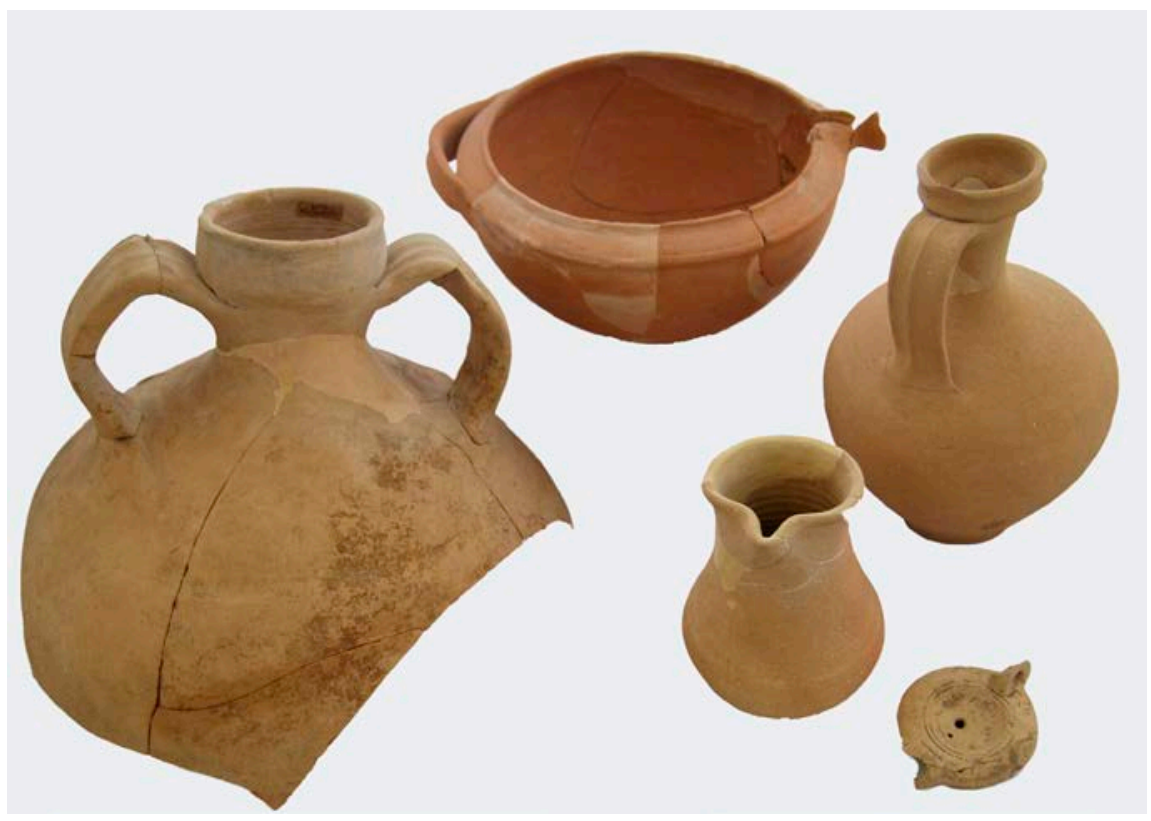

Fig. 14: Selecció ceràmica de l'amortització de la claveguera i el desguàs del carrer del Mar núm. 19.

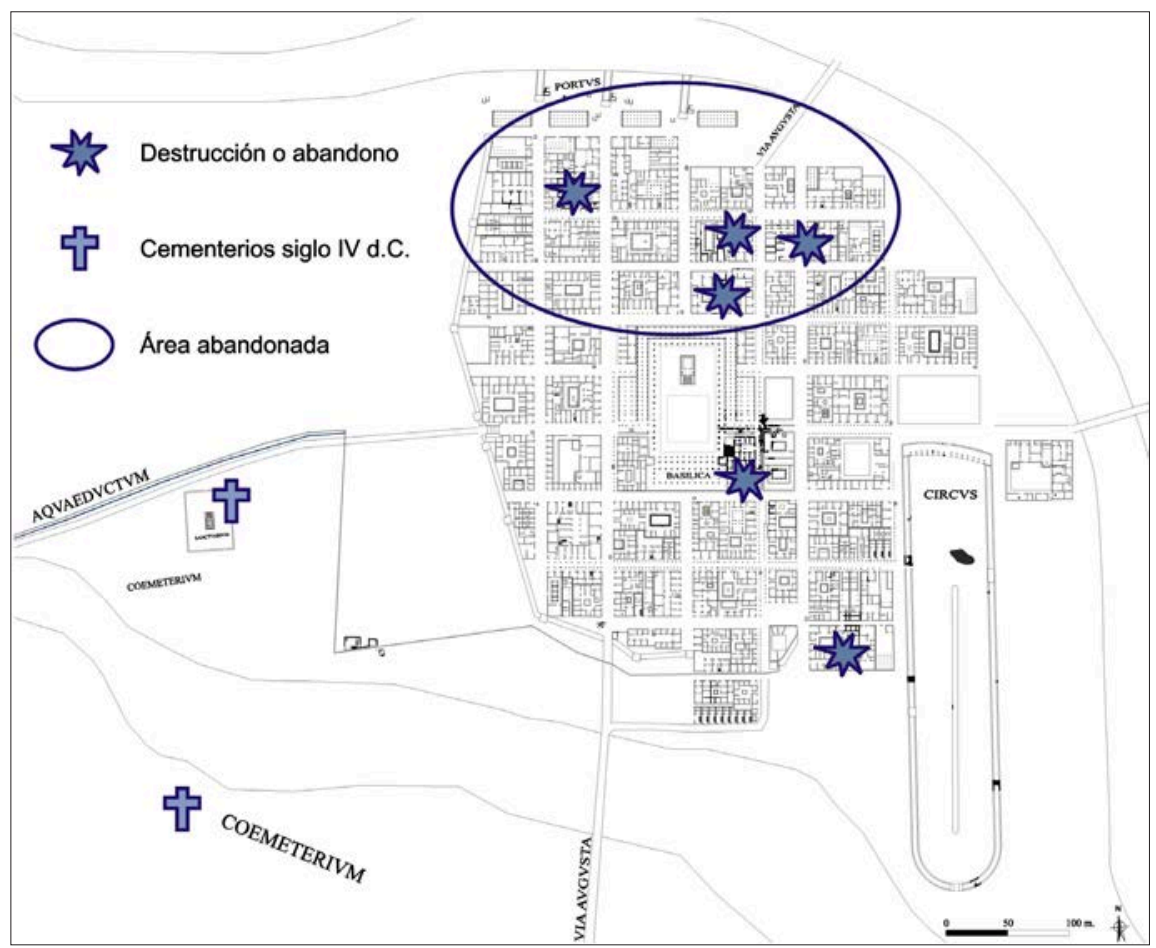

Fig. 15: Plànol de destruccions i abandonaments del s. III d.C. (Ribera i Jiménez 2014: 158, modificat per E. Huguet).

algunes peces de TSA A de formes clàssiques i de més tardanes, TSA A/D i TSA C, encara que considerem com a intrusió un fragment de la forma Hayes 53 datada en el s. IV (Hayes 1972). No apareix cap altre fragment de TSA D. Tampoc no apareixen les formes evolucionades de les cassoles Hayes 23 i Òstia III, 267 d'africana de cuina (Bonifay 2004: 224). Hi són absents les olles de parets baixes reductores de cuina de procedència murciana, "fabric 7" (Reynolds 1993: 148 i 152), les cassoles a mà/torneta de procedència alacantina documentades en 
el s. IV d.C. i les importacions de les illes centrals del Mediterrani datades entre el s. IV i el VI d.C. (Fulford i Peacock 1994: 167). Per tant, la formació d'aquesta U.E. aporta també informació cronològica del moment d'utilització de la claveguera com a femer i la seua falta de manteniment però a més indica el final de la canalització que probablement desguassava en una mena de barranc o en una zona topogràficament més baixa que la base de la claveguera.

El taponament d'aquesta cloaca exemplifica el procés de decadència urbana que experimentà la ciutat en el s. III d.C., quan es reduí la superfície ocupada. El s. II d.C. fou un període de relativa calma en el qual es mantingueren les construccions anteriors sense excessius canvis, més enllà de remodelacions i obres de millora en diferents edificis públics i privats. Des de la primera meitat del s. III d.C., la ciutat donà signes d'esgotament, quan s'abandonaren algunes construccions com la dels Banys de l'Almirall i potser també el santuari periurbà de la plaça del Marqués de Busianos (Arnau et al. 2003: 186), que són més evidents a partir de mitjan del s. III d.C. quan l'obturació del clavegueram, l'abandonament d'infraestructures i els nivells d'incendi en diferents punts de la ciutat es constaten de manera reiterada. Malgrat l'obstrucció de les clavegueres, l'entramat viari continuà en ús tant en la Baixada dels Toledans com en la plaça de Cisneros (Ribera i Romaní 2011: 338), cosa que unit a l'epigrafia honorífica, datada majoritàriament entre final del s. II i el III d.C., sembla indicar que els òrgans de govern de la ciutat encara funcionaven a les acaballes del s. III d.C. Tot i que no es coneixen els motius exactes d'aquest declivi, s'han documentat episodis violents urbans, materialitzats en incendis i/o abandonaments dels edificis, sobretot en la zona $\mathrm{N}$ de la ciutat com ara al Palau de les Corts Valencianes (López et al. 1990: 30), al barri portuari i comercial nord-oriental (Ribera 2008) i a la basílica del fòrum (Ribera i Jiménez 2014: 158) (fig. 14). Les estructures del port fluvial del carrer Comte de Trénor quedaren en desús també en aquest moment (Ribera 2008: 39), com també el recinte funerari del carrer Sagunt (Van Andriga et al. 2007: 171). El col-lapse manifestat en la urbs coincidí amb l'ocultació de 89 monedes entre les bigues del sostre de l'edifici del carrer Roc Chabàs entre el 270 i 280 d.C. (Ribera i Salavert 2005: 141), data proposada també per als episodis d'incendis i destruccions (Ribera i Jiménez 2012: 10; Jiménez et al. 2014: 269).
Les terrisseries locals i regionals mostren canvis en paral·lel als moments convulsos de la ciutat. L'estudi de la ceràmica comuna i de cuina de producció local i regional a Valentia en aquesta època ha demostrat tant una transformació a nivell tècnic com a nivell formal (Huguet 2016: 561). Pel que fa als aspectes tècnics es constata un canvi en la depuració de les argiles que contenien en general una major quantitat de desgreixants de porcions menys fines i als tradicionals desgreixants calcaris blancs i brillants de la zona, s'afegeixen d'altres també calcaris de calcària grisa. A més, varia la consistència de les argiles utilitzades per a la confecció dels productes, que són menys compactes, més toves i més plàstiques, i també dels acabats generals, entre els quals es característic la manca de cura en l'elaboració i unió de les anses als recipients tancats, que en ocasions semblen únicament units amb un simple pessic. Per últim, es documenten també canvis en la morfologia dels recipients amb una evolució del repertori clàssic de recipients tancats, en menor mesura també oberts, i amb l'aparició de noves formes que enllaçaran amb l'antiguitat tardana.

\section{BIBLIOGRAFIA}

ALBIACH, R.; MARÍN, C.; PASCUAL, G.; PIÀ, J.; RIBERA, A.; ROSSELLÓ, M; SANCHIS, A. (1998): La cerámica de época de Augusto procedente del relleno de un pozo en Valentia (Hispania Tarraconensis), Actes du Congrès d'Istres, SFECAG, Marsella, 139-166.

BONIFAY, M. (2004): Etudes sur la céramique romaine tardive d'Afrique, BAR-I.S. 1301, Oxford.

ESCRIVÀ, V. (1995): Cerámica común romana en el Municipium Liria Edetanorum. Nuevas aportaciones al estudio de la cerámica de época alto imperial en la Hispania Tarraconensis, Ceràmica comuna romana d'època Atlo-Imperial la Península Ibèrica. Estat de la qüestió, Girona, 167-186.

FULFORD, M. G; PEACOCK, D. P. S. (1994): The Circular Harbour, Nord Side. The pottery. Excavations at Carthage: british mission, Vol II, Oxford.

HAYES, J. W. (1972): Late Roman Pottery, British School at Rome, London.

HUGUET, E. (2012): Cerámica Regional Reductora de cocina Altoimperial de la fachada mediterranea, Cerámicas Hispanorromanas II. Producciones Regionales (D. Bernal, A. Ribera, coords.), Cádiz, 435-452.

HUGUET, E. (2016): La ceràmica comuna de la ciutat romana de Valentia (segle II aE-III $d E$ ), Tesi Doctoral, Universitat de València, València. 
HUGUET, E.; RIBERA, A. (2014): Contextos ceràmics alt-imperial de Valentia, Contextos cerámicos de época imperial en el mediterráneo Occidental, Barcelona, 150-180.

HUGUET, E.; RIBERA, A. (2015): La vajilla usada en las ofrendas rituales en Valentia: ceràmica específica i general, Actes $d u$ Congrès du Nyon, SFECAG, Marsella, 221-244.

JIMÉNEZ, J. L. (2009): Una nueva imagen urbana, La Ciudad de Valencia. Historia, Colegio Territorial de Arquitectos de Valencia, València, 92-100.

MARANGOU-LERAT, A. (1995): Le vin et les amphores de Crète de l'epoque clàssiques à l'epoque impériale, Études crétoises 30, École Française d'Athenes i Fondation Fany Boutari, Paris.

LÓPEZ, I.; MARÍN, C.; MARTÍNEZ, R.; MATAMOROS, C. (1990): Troballes arqueològiques al Palau de les Corts, Corts Valencianes, València.

PASCUAL, J. (1988): Informe previo de los resultados obtenidos en la excavación de urgència realitzada en el solar $n^{\circ} 19$ de la calle del Mar (Valencia), Inèdit, València.

PAZ PERALTA, J. A. (2008): Las produccions de Terra Sigillata Intermedia y Tardía, Ceramicas Hispanorromanas. Un estado de la Cuestión, Cádiz, 497-539.

REYNOLDS, (1993): Settlement and pottery in the Vinalopó Valley (Alicante, Spain) A.D.400- 700, B.A.R.-I.s. 588, Oxford.

RIBERA, A. (2008): Puertos y arquitectura comercial en la Valencia antigua: los orígenes de una larga tradición, Historia de la Ciudad V: Tradición y progreso, Colegio Territorial de Arquitectos de Valencia, València, 29-40.
RIBERA, A.; JIMÉNEZ, J. L. (2012): Valentia, ciudad romana: su evidencia arqueológica, Hispaniae Urbes (Sevilla, 2010), Sevilla, 77-120.

RIBERA, A.; JIMÉNEZ, J. L. (2014): La imagen urbana de Valentia, Las ciudades romanas valencianas, MARQ Museo Arqueológico de Alicante, Alicante, 143-160.

RIBERA, A.; JIMÉNEZ, J. L.; ROSSELLÓ, M. (2014): Valentia y su territorium desde época romana imperial a la antigüedad tardía: una síntesis, Monografías de Arqueología Cordobesa 20, 265-282.

RIBERA, A.; ROMANÍ, N. (2011): Valentia, La gestión de los residuos urbanos en Hispania, Anejos de AEspA LX, Mérida, 313-342.

RIBERA, A.; SALAVERT, J. V. (2005): El depósito monetal del siglo III de las excavaciones de la calle Roque Chabàs de Valencia, Tesoros monetales de Valencia y su entorno. Grandes Temas Arqueológicos 4, Ajuntament de València, València, 141-154.

TORTORELLA (1981): Ceramica africana da cucina, Atlante delle forme ceramiche I, Enciclopedia dell'arte antica, Roma, 208-227.

VAN ANDRIGA, W.; ALAPONT, L.; MARTÍNEZ, R. (2007): La necrópolis de Porta Nocera de Pompeya y otros ritos funerarios de Valentia, Pompeya bajo Pompeya. Las excavciones de la Casa de Ariadna (A. Ribera, M. H. Olcina, C. Ballester, eds.), València, 160-178. 